\title{
Glikoz İzomeraz Üreticisi Dört Geobacillus Suşunun İzolasyonu ve Moleküler Metotlar Kullanarak Tanımlanması
}

\author{
Isolation of Four Glucose Isomerase Producing Strains of Geobacillus and Their \\ Identification Using Molecular Methods
}

\author{
Kadriye İNAN BEKTAŞ*
}

Karadeniz Teknik Üniversitesi, Fen Fakültesi, Moleküler Biyoloji ve Genetik Bölümü, 61080, Trabzon

• Geliș tarihi / Received: 06.06.2017 • Düzeltilerek geliş tarihi / Received in revised form: 28.02.2018 • Kabul tarihi / Accepted: 27.03 .2018

\section{$\ddot{O} z$}

Türkiye'nin batısındaki iki kaplıca, termofilik mikroorganizmaların mevcudiyetine göre araştırıldı ve iki termal kaplıcadan,23 termofilik bakteri izole edildi. İzolatlardan, 4 tanesinin glikoz izomeraz üretimi açısından pozitif olduğu belirlendi. BT5, CT6SARI ve CT1.2 izolatlarının glikoz izomerazları, $\mathrm{pH} 6.5$ 'te optimum büyüme gösterdi; buna karşıllk izolat BT1 enzimi, pH 7.5'te optimal aktivite gösterdi. Bu enzimler arasında BT1 izolatının optimal büyüme sıcaklı̆g $175^{\circ} \mathrm{C}$ olarak belirlenirken, diğer üç izolatın enzimleri ise $80^{\circ} \mathrm{C}$ 'de optimal büyüme gösterdi. $16 \mathrm{~S}$ rRNA gen dizi analizleri ile 4 izolatın, Geobacillus cinsine ait türler oldukları belirlendi. recN dizisi benzerlik analizine dayanarak, izolat CT6SARI'nın, G. termodenitficans'a; izolat BT1'in de, G. stearothermophilus'a ait suşlar oldukları belirlendi.BT5 ve CT1.2 izolatlarının kesin tür tayinleri yapılamadı.

Anahtar kelimeler: Geobacillus, Glikoz izomeraz, recN, 16S rRNA

\begin{abstract}
Two hot springs located in west of Turkey were investigated with respect to presence of thermophilic microorganisms. 23 thermophilic bacteria were isolated from two hot springs. Among these, 4 strains were found positive for glucose isomerase production. The glucose isomerases of strains BT5, CT6SARI and CT1.2 showed optimal growth at pH 6.5, whereas the enzyme of strain BT1 represented optimal activity at pH 7.5. The strain BT1 had the lowest temperature optima $\left(75^{\circ} \mathrm{C}\right)$ among these strains whereas the other three strains showed optimal growth at $80^{\circ} \mathrm{C}$. On the basis of the $16 S$ rRNA gene sequence analysis, the 4 isolates are members of the genus Geobacillus. Based on recN sequence similarity analysis, the isolate CT6SARI is a strain of G. thermodenitficans. The isolate BT1 is a strain of G. stearothermophilus. The species identity for the isolates BT5 and CT1.2 are uncertain.
\end{abstract}

Keywords: Geobacillus, Glucose-isomerase, recN, $16 \mathrm{~S}$ rRNA

* Kadriye İNAN BEKTAŞ; kadriyensis@gmail.com; Tel: (0462) 37735 72; orcid.org/0000-0002-5909-588X 


\section{Giriş}

Geobacillus cinsi, Bacillus cinsinden ayrılmış olup, tip türü Geobacillus stearothermophilus'tur. Termofilik, asidofilik, alkalifilik ve halofilik özelliklere sahip birçok tür bu cinse dâhil edilmiştir (Nazinavd., 2001). Bu türlerin geleneksel biyokimyasal tekniklerle tanımlanması, kesin olmayan ve zaman alıcı bir işlemdir. Prokaryotik organizmalar boyunca oldukça korunan 16S rRNA gen dizilerinin analizleri, filogenetik ilişkileri belirlemek için en yaygın şekilde kullanılmaktadır (Meintanisvd., 2008). Bununla birlikte, 16S rRNA geninin siklikla, yakından ilişkili bazı türler arasındaki filogenetik ilişkilerin çözümlenmesi için yetersiz olduğu da kanıtlanmıştır (La Ducvd., 2004). Bu nedenle, pek çok teknik mevcut olsa da, DNA-DNA hibridizasyon değerlerinin analizi bakteri türlerini tanımlamak için "altın standart" olarak kabul edilmektedir (Stackebrandt ve Goebel 1994; Stackebrandt vd., 2002; Zeigler, 2003). Ancak, hibridizasyon yöntemleri çoğunlukla özel ekipman ve çok fazla zaman gerektirdiği için, laboratuarlar arasındaki hibridizasyon değerlerinin gerekli hassasiyetle tekrarlanabilmesi zor olmaktadır. Sonuç olarak; sistematik, DNA dizilerinin özellikle protein kodlayan gen dizilerinin karşılaştırılmasına giderek daha fazla güvenilir sonuçlar elde etmeye başlamıştır (Stackebrandt ve Goebel, 1994). Son zamanlarda, bakteriyel sistematikte kullanılabilen otuzdan fazla gen tespit edilmiş olup; bunların arasında DNA onarımı ve genetik rekombinasyon protein $(r e c N)$ geni, genom benzerlik tahmini için en güçlü adaylardan biridir (Zeigler, 2005). recN dizi benzerlik skorları, iki organizma tarafindan paylaşılan bütün genom dizisi benzerliğini yüksek bir doğruluk derecesinde tahmin edebilir. İncelenen türler için, $r e c N$ analizi ile öngörülen genom benzerlik skorları doğrudan genomik hizalanmalarda ölçülenlerden sadece $\% 4.4$ oranında farklıdır. Geobacillus cinsi için, recN, 16S rRNA geninden açıça üstün olup, tür düzeyinde çok daha büyük bir çözünürlük gücü vardır. Böylece recN, Stackebrandt vd.'lerinin (2002) gereksinimlerini karşılamaktadır ve Geobacillus cinsi içindeki türlerin tayini için başarıyla kullanılmaktadır (Zeigler, 2005).

Endüstriyel açıdan önemli termostabil enzim kaynakları olmaları nedeniyle, Bacillus cinsi termofilik endospor oluşturan bakteriler, son yıllarda önemli bir çalışma alanı olmuştur (Beg vd., 2000; Touzel vd., 2000). Proteazlar, amilazlar, pullulanazlar, peroksidaz, glukozizomerazlar, lipazlar, ksilanlar ve DNA kesim enzimleri gibi endüstriyel açıdan önemli pekçok termostabil enzimlerin kaynağı olma potansiyelleri nedeniyle bu termofilik basillerin önemi artmıştır. Glikoz izomerazlar, gıda, yem, tekstil endüstrisi, hemiselülozdan etanol üretimi ve atık arıtımı gibi pekçok endüstri alanında geniş olarak kullanılmaktadır. Bu işlemlerin çoğu, yüksek sıcaklıklarda gerçekleştirildiği için, termostabil enzimler büyük avantaj sağlamaktadır (Bhosale vd., 1996; Brosius vd., 1978; Calik vd., 2009; Canakci vd., 2007).

Glukozun fruktoza, ksilozun ksiluloza isomerizasyonunu katalizleyen ve ksiloz izomeraz olarak da adlandirılan glukoz izomeraz (Dxyloseketol-isomerase E.C 5.3.1.5) birçok mikroorganizmada bulunmaktadır. Bu enzim, hem hemisellülozdan etanol üretimine yardımcı olduğu için hem de früktoz şurubu diğer adıyla HFCS (High Fructose Corn Syrup) üretiminde kullanıldığı için büyük endüstriyel öneme sahiptir. Özellikle glukozu früktoza dönüştürerek HFCS üretiminde kullanımı ile glukoz izomeraz, gida endüstrisinde en çok kullanılan enzimlerden biri haline gelmiştir (Calik vd., 2009). Fruktoz şurubu; $\% 42$ veya 55 fruktoz içeren tatl, besleyici sakkarit karışımı olup, mısır nişastası glukozunun GI enzimi kullanılarak fruktoza dönüştürülmesi ile elde edilen bir üründür (Bandlish vd., 2002; Mu vd., 2012).HFCS'nin başlıca kullanım alanları içecek, firıncilık, konserve ve şekerleme endüstrileridir (Bhosalevd.,1996).

HFCS sürecinde, fruktoz:glikoz dengesinin nihai konsantrasyonu, sıcaklıklara bağlıdır. HFCS üretiminde mezofilik organizmalardan elde edilen glikoz izomeraz enzimleri ile \%40-42 oranında fruktoz üretilebilmektedir. Fakat endüstriyel uygulamalarda kullanılan HFCS'de \% 55 fruktoz içeriği aranmaktadır. Dolayısı ile bu oran kromatografik olarak \%55 seviyelerine getirilir. Fakat bu işlem üretim maliyetini arttırmaktadır. Sicaklığın artmasıyla fruktoz-glukoz dengesi fruktoz tarafina kaymakta böylece pahalı olan kromatografik saflaştırmaya gerek kalmamaktadır (Bhosale, 1996; Karaoğlu vd., 2013; Xu vd., 2014). Bu yüzden bu uygulamalarda yüksek sıcaklıklarda çalışan termofilik mikroorganizmalardan elde edilen enzimler tercih edilmektedir (Hartley vd., 2000; Yanmis vd., 2014). Fakat yüksek $\mathrm{pH}$ değerlerinde yüksek sicaklık uygulamalar1, istenmeyen mannoz, psikoz ve diğer asidik yan ürünlerin oluşumuna sebep verdiğinden düşük $\mathrm{pH}$ değerlerinde çalışan bir enzime ihtiyaç bulunmaktadır (Karaoğlu vd., 2013; Xu vd., 2014). Ayrıca, ticari olarak glikoz izomeraz uygulaması, nişasta sıvılaştırma ve 
glikoz izomerleşmesinin tek bir aşamada gerçekleştirilebilmesini mümkün kılmak için asidik bir optimumpH'ya ihtiyaç duymaktadır. Elde edilebilir en yüksek fruktoz seviyesini arttırmak için termostabil ve asidik ortamda aktif glikoz izomerazlara ihtiyaç duyulmaktadır. Bu nedenle bu özelliklere sahip glikoz izomeraz üretebilen yeni mikroorganizmaları bulmak endüstriyel açıdan oldukça önem arz etmektedir (Calik vd., 2009).

$\mathrm{Bu}$ çalışmada, Hisarköy Kaplıcası (Balıkesir) ve Hıdırlar Kaplıcasından (Çanakkale) izole edilen bazı termofilik Geobacillus suşları üzerinde moleküler tanımlama çalışmaları yapıldı. $\mathrm{Bu}$ suşların glikoz izomeraz aktiviteleri araştırıldı ve endüstriyel kullanım potansiyelleri belirlendi.

\section{Araç ve Yöntemler}

\section{1. Örnekleme ve İolasyon}

$\mathrm{Bu}$ çalışmada, Hisarköy Kaplıcası (Balıkesir) ve Hıdırlar Kaplıcasın'dan (Çanakkale) toplanan çamur ve su örneklerinden, termofilik bakteriler izole edilmiştir. Bu kaplıcaların su sıcaklığ 70 $130{ }^{\circ} \mathrm{C}$ arasındadır. Kaplıcaların çamur ve su örnekleri $4^{\circ} \mathrm{C}^{\prime} \mathrm{de}$ laboratuvara getirilmiş ve bu numuneler hemen Luria-Bertani (LB) besiyerinde $60{ }^{\circ} \mathrm{C}^{\prime} \mathrm{de}$ zenginleștirme için kullanılmıştır. Bir günlük zenginleştirme kültürlerinin, $10 \mathrm{ml}$ de Luria-Bertani sıvı ortamında alt kültürleri yapıldı ve Triptik Soy Agar petrilerine çizgi ekim gerçekleştirildi. Birbirlerinden farklı koloni morfolojisine sahip olduğu düşünülen koloniler seçildi ve izole edildi. İzolasyon için kullanılan yöntem daha önceki çalışmamızda detaylı bir şekilde açıklanmıştır (Inan vd., 2011). İzolatların saflı̆̆ 1 ve koloni morfolojisi mikroskop ile kontrol edildi.

\subsection{Glikoz İzomeraz Aktivitesi}

Tüm izolatlar, LB besiyerinde $60{ }^{\circ} \mathrm{C}$ 'de bir gece çoğaltıldılar. Gece kültürlerinden, optik yoğunluk (O.D.) 0.1 olacak şekilde taze LB besiyerlerine yeniden ekim yapıld 1 ve O.D. 0.6 oluncaya kadar $60{ }^{\circ} C^{\prime}$ de çalkalamaya bırakıldılar. Glikoz izomerazın ekspresyonu için O.D. 0.6'da (600 $\mathrm{nm})$ son konsantrasyon \% 0.5 olacak şekilde Dksiloz ile indüklendiler ve 4 saat daha $60{ }^{\circ} \mathrm{C}$ 'de çalkalandılar. Hücreler, 11.000 rpm'de 5 dakika santrifüjlenerek toplandı ve çöken hücreler ve 50 $\mathrm{mM}$ MOPS (pH6.5) tamponu ile çözüldüler. Ardından hücre içi proteinleri salmak için Sartorius Labsonic marka sonikatörile hücreler patlatıldı. Hücre kalıntılarını gidermek için 14.800 rpm'de 15 dakika santrifüj edildi. Pellet kısmı atıldı ve sıvı kısmı oluşturan hücre özütü, enzim kaynağı olarak glikoz izomeraz aktivitesi bakıldı.

Glikoz izomeraz aktivitesi, Belfaquih ve arkadaşları (2000) tarafından geliştirilen metod ile tayin edildi. $10 \mathrm{mM} \mathrm{MgSO}_{4}, 1 \mathrm{mM} \mathrm{CoCl} 2,0.1 \mathrm{M}$ glikoz ve farklı hacimlerde enzim özütü, $50 \mathrm{mM}$ MOPS tamponunda ( $\mathrm{pH}$ 7.0) $100 \mu$ l tepkime hacminde 30 dakika boyunca $85{ }^{\circ} \mathrm{C}^{\prime}$ de inkübe edildi. Üzerine $100 \mu 10.5 \mathrm{M}$ perklorik asit ilave edilerek reaksiyon durduruldu. Enzim reaksiyonundan sonra oluşan fruktoz miktarı, sistein-karbazol-sülfürik asit yöntemi (Dische ve Borenfreund, 1951) ile tayin edildi. Reaksiyon çözeltisi üzerine, $40 \mu 1 \% 1.5$ sistein hidroklorür ve $40 \mu 1 \% 0.12$ karbosol eklendi ve vortekslendi. Üzerine1.2 ml \% 70 sülfürik asit ilave edilip, tekrar vorteks yapıldı ve oda sicaklığında 30 dakika inkübe edildi. Spektrofotometrede $560 \mathrm{~nm}$ dalga boyunda ölçümler gerçekleştirildi.

Sicaklığın glikoz izomeraz aktivitesine etkisi, 250 $\mathrm{mM}$ glukoz varlığında MOPS tamponunda $(\mathrm{pH}$ 6.5) belirlendi. Glikoz izomerazın en iyi çalıştı̆̆ optimum sicaklık değeri $25,37,45,55,60,65,70$, $75,80,85,90,95$ ve $100{ }^{\circ} \mathrm{C}$ de ayarlanmış isitıcı bloklarda gerçekleştirilen seri reaksiyonlar sonucu belirlendi.

Glukoz izomeraz aktivitesine pH'in etkisi farkl1 $\mathrm{pH}$ aralığındaki çeşitli tamponlarda, $250 \mathrm{mM}$ glukoz konsantrasyonunda, $85^{\circ} \mathrm{C}$ 'de 30 dakikalık reaksiyon şartlarında incelendi. Asetat tamponu $\mathrm{pH} 5$ - 5.5; fosfat tamponu $\mathrm{pH} 6-7.0$; Tris- $\mathrm{HCl}$ tamponu $\mathrm{pH} 7.5$ - 9.0 ve glisin tamponu $\mathrm{pH} 9.5-$ 10.0aralığında kullanıldı.

\subsection{Glikoz İzomeraz Üreten İzolatların Morfolojik Karakterizasyonu}

Glikoz izomeraz üreten izolatların hücre morfolojisi ve hareketi, logaritmik fazdaki sıv1 kültürlerin faz-kontrast mikroskobunda (Nikon Eclipse E600; Olympus) incelenmesiyle belirlendi. Kolonilerin morfolojisi ve pigmentasyonu, $60^{\circ} \mathrm{C}^{\prime}$ de 1 günlük inkübasyondan sonra Triptik Soy Agar üzerinde gözlemlendi.

Ardından izolatların hücre duvarı özelliklerinin ortaya çıkarılması amacıyla Gram boyama yapıldı ve bu yönteme göre izolatların Gram boyama tipleri belirlendi (Dussault, 1955; Powers, 1995). İzolatların spor yapılarını oluşturup oluşturmad1ğının ve sporun hücre içerisindeki pozisyonunun belirlenmesi amaciyla, spor boyamalar yapıldı (Smibert ve Krieg, 1994). 


\subsection{S rRNA ve recN Gen Dizilerinin PCR Amplifikasyonu ve Klonlanmast}

16S rRNA genleri, izole edilen genomik DNA'dan, bakteriyel 16S rRNA genlerinin 5've 3' bölgelerindeki korunmuş bölgelere bağlanacak şekilde tasarlanmış oligonükleotit primerler kullanılarak seçici olarak çoğaltıldı. İleri primer, UNI16S-L $(5 '-$ ATTCTAGAGTTTGATCATGGCTTCA), Escherichia coli 16S rRNA'nı 11-26 pozisyonlarına karşıllık gelirken; geri primer, UNI16S-R $(5$ 'ATGGTACCGTGTGACGGGCGGTGTTGTA), E. coli $16 \mathrm{~S}$ rRNA'nın 1411 ila 1393 pozisyonlarının tamamlayıcısı şeklinde dizayn edilmiştir (Brosiusvd., 1978). PCR reaksiyonlarının şartları Beffa ve arkadaşlarına (1996) göre oluşturuldu. PCR reaksiyonu ile çoğaltılan 16S rRNA genleri, pGEM-T Easy Klonlama Kiti kullanılarak, pGEM-T Easyklonlama vektörüne firmanın öngördüğü konsantrasyonlar ve şartlar gerçekleştirilerek klonlandi.

recN genleri, Geobacillus spoIVB ve ahrC genlerinin (Zeigler, 2003) 5 've 3' bölgelerindeki korunmuş bölgelere bağlanacak şekilde tasarlanmış oligonükleotit primerler kullanılarak, izole edilen genomik DNA'dan PCR yardımı ile çoğaltıldı. F1-2- (5'-CGA TTT GCG GCG ACG ATA C-3 ') ileri primeri ve R1-1- (5'-TAC ACC ATG CAA AAA CGG TTA C-3') geri primeri olarak kullanılmıştır. PCR reaksiyonlarının şartları Zeigler'e (2003) göre oluşturuldu ve elde edilen $r e c N$ dizileri pGEM-T Easy vektör sistemi kullanılarak klonlama yapıldı.

Klonlanan 16S rRNA ve recN genlerinin baz dizin analizi, otomatik dizi analizatörleri aracılı̆̆ 1 ile (Macrogen, Hollanda) belirlendi. recN geninin yaklaşık $1600 \mathrm{nt}$ ve $16 \mathrm{~S}$ rRNA genin de yaklaşık 1400 nt'likbaz dizileri belirlendi. Bu diziler, BLAST araması (Altschulvd., 1990) kullanılarak GenBank'ta var olan diğer bakteriyal dizilerle karşılaştırıldı ve aralarındaki benzerlik oranları belirlendi (Bensonvd., 1999).

16S rRNA ve recN gen dizileri, çoklu hizalama programı olan CLUSTAL W programı kullanılarak hizalandı (Thompsonvd., 1994). Kimura'nın iki parametre modeli (Kimura, 1980) kullanılarak evrimsel uzaklıklar hesaplandı ve filogenetik analizler neigbour-joining yöntemi ile gerçekleştirildi (Sharmavd., 2008). Filogenetik ağaçlar, MEGA4 paket programı (Felsenstein 1985; Tamuravd., 2007) kullanılarak oluşturuldu.

\section{Bulgular ve Tartışma}

\subsection{Bakteri İzolasyonu ve Glikoz Izomeraz Aktivitesinin Belirlenmesi}

Glikoz izomeraz, glukozu fruktoza izomerize etmesi sebebiyle endüstriyel alanda, özellikle HFCS üretiminde ticari bir öneme sahiptir. Glikoz izomeraz, sahip olduğu bu endüstriyel önem nedeniyle bugüne kadar birçok bilim insanı tarafından çalışılmış olup, farklı glikoz izomeraz üreticilerinin tipik olarak orta dereceli mezofilikler olduğu bilinmektedir (Abdel-rassol vd., 2012; Karaoğlu vd., 2013). HFCS üretiminde sicaklığın artmasiyla fruktoz-glukoz dengesi fruktoz tarafina kaymakta böylece pahalı olan kromatografik saflaştırmaya gerek kalmamaktadır (Bhosale, 1996; Xu vd., 2014). Bu yüzden bu uygulamalarda yüksek sıcaklıklarda çalışan termofilik mikroorganizmalardan elde edilen enzimler tercih edilmektedir.

$\mathrm{Bu}$ ihtiyaçlardan dolayı bizde bu çalışmada, pek çok araştırmacı gibi termofilik karakterli bakterilerin glikoz izomerazlarını araştırdık. $\mathrm{Bu}$ çalışma kapsamında Hisarköy Kaplıcasından (Balıkesir) 10 ve Hidirlar Kaplicasından (Çanakkale) 13 izolat olmak üzere toplam 23 termofilik bakteri izole edildi. 23 izolatın glikoz izomeraz aktiviteleri araştırıldı ve sadece 4 izolatın (BT1, BT5, CT6SARI ve CT1.2) glikoz izomeraz aktivitesine sahip olduğu belirlendi. Bu izolatların ürettikleri glikoz izomerazların, optimum sicaklık ve $\mathrm{pH}$ değerleri belirlendi. Sicaklığın glikoz izomeraz aktivitesi üzerine etkisi, $\quad 25-100{ }^{\circ} \mathrm{C}$ aralığında spektrofotometrik olarak test edildi. İzolatlar arasında, BT1'in glikoz izomerazının en düşük optimum sıcaklığa $\left(75^{\circ} \mathrm{C}\right)$ sahip olduğu, diğer 3 izolatın (BT5, CT6SARI ve CT1.2 ) enzimlerinin ise optimum sıcaklıklarının $80^{\circ} \mathrm{C}$ olduğu belirlendi (Tablo 1 ).

HFCS üretiminde mezofilik organizmalardan elde edilen glikoz izomerazlar, ticari olarak immobilize edilmiş bir şekilde $55-65{ }^{\circ} \mathrm{C}$ 'de $\mathrm{pH} 7.5$ ile 8.5 aralığında kullanılmaktadır (Schenck, 2000; Xu vd., 2014).Termofilik A. gonensis glikoz izmerazının optimum $85{ }^{\circ} \mathrm{C}$ 'de aktivite gösterdiği bulunmuştur (Karaoğlu vd., 2014). Benzer şekilde Streptomyces sp. (Inyang vd., 1995) ve Bacillus sp.(Chauthaiwale vd., 1994) türlerine ait glikoz izomerazların optimum çalışma sicaklıklarının da $85^{\circ} \mathrm{C}$ olduğu gösterilmiştir. Thermotoganea politana glikoz izomerazının ise optimum $95^{\circ} \mathrm{C}$ 'de çalıştığı gösterilmiştir (Hess vd., 1998). 
Tablo 1. İzolatların ürettikleri glikoz izomerazların sıcaklık-aktivite (\%) tablosu.

\begin{tabular}{|c|c|c|c|c|}
\hline \multirow{2}{*}{$\begin{array}{l}\text { Sicaklık } \\
\left({ }^{\circ} \mathrm{C}\right)\end{array}$} & \multicolumn{4}{|c|}{ Aktivite (\%) } \\
\hline & BT1 & BT5 & CT6SARI & CT1.2 \\
\hline 25 & 5 & 10 & 12 & 8 \\
\hline 37 & 9 & 15 & 15 & 13 \\
\hline 45 & 14 & 20 & 21 & 20 \\
\hline 55 & 23 & 36 & 34 & 35 \\
\hline 60 & 43 & 40 & 41 & 39 \\
\hline 65 & 75 & 51 & 50 & 47 \\
\hline 70 & 95 & 80 & 85 & 78 \\
\hline 75 & 100 & 89 & 95 & 89 \\
\hline 80 & 85 & 100 & 100 & 100 \\
\hline 85 & 71 & 90 & 94 & 88 \\
\hline 90 & 65 & 78 & 84 & 80 \\
\hline 95 & 41 & 70 & 55 & 68 \\
\hline 100 & 23 & 40 & 25 & 51 \\
\hline
\end{tabular}

$\mathrm{Bu}$ glikoz izomerazlar haricindeki diğer glikoz izomerazlar genel olarak optimum $60^{\circ} \mathrm{C}$ ile $80^{\circ} \mathrm{C}$ arasında aktivite göstermektedirler. $\mathrm{Bu}$ verilere dayanılarak, $80^{\circ} \mathrm{C}$ 'lik optimum çalışma sıcaklığı ile BT5, CT6SARI ve CT1.2 glikoz izomerazlarının termofilik enzimler olduğu söylenebilir.

Ticari olarak glikoz izomeraz uygulaması, nişasta sıvılaştırma ve glikoz izomerleştirme işlemlerinin tek bir aşamada gerçekleştirilmesini sağlamak için, optimum asidik bir $\mathrm{pH}$ istemektedir. Düşük pH'ta izomerizasyon avantajından dolayı, ticari olarak glukoz izomeraz uygulamaları için asidik pH'lar arzu edilir. (Karaoğlu vd., 2013; Xu vd., 2014). Bununla birlikte, endüstride kullanılan mevcut glikoz izomerazların optimum $\mathrm{pH}$ aralığ ise genellikle pH 7.0 ile 9.0 arasındadır (Benson vd., 1999, Karaoğlu vd., 2013). Bu nedenle, asidik ortamda yüksek aktivite gösteren glikoz izomerazlar endüstride aranan enzimlerdir ve araştırmacılar sanayide hâli hazırda kullanılanlardan daha fazla asidik ve termostabil enzim üretebilen mikroorganizmaları izole etmeye yönelik çalışmalar yapmaktadırlar.

$\mathrm{Bu}$ çalışma kapsamında izole edilen glikoz üreticisi 4 bakterinin glikoz izomerazın aktivitesi, 5.0 ila 10.0 arasındaki $\mathrm{pH}$ aralığında test edildi. BT5, CT6SARI ve CT1.2 izolatlarının ürettikleri glikoz izomerazların, $\mathrm{pH}$ 6.5'te optimum aktivite gösterdikleri; BT1 izolatının glikoz izomerazının ise, $\mathrm{pH} 7.5$ 'te optimum aktivite gösterdiği belirlendi (Tablo 2).

Birçok glikoz izomeraz enziminin optimum aktiviteleri genel olarak $\mathrm{pH} 7.0$ ila 9.0 arasinda değişen 6.5'den yüksek pH'larda gözlenmiştir (Karaoğluvd., 2013). Thermoanaerobacterium sp. (Liu vd., 1996), Lactobacillus brevis (Yamanaka, 1975), Thermus aquaticus (Lehmbacher, 1990), Anoxybacillus gonensis (Karaoğlu vd., 2013) glikoz izomerazları haricindeki diğer glikoz izomerazların optimum $\mathrm{pH}$ değeri 6.5 'ten yukarıdır.

Tablo 2. İzolatların ürettikleri glikoz izomerazların pH-aktivite (\%) tablosu

\begin{tabular}{|c|c|c|c|c|}
\hline \multirow{2}{*}{ pH } & \multicolumn{4}{|c|}{ Aktivite (\%) } \\
\hline & BT1 & BT5 & CT6SARI & CT1.2 \\
\hline 5 & 6 & 5 & 8 & 4 \\
\hline 5.5 & 28 & 30 & 26 & 39 \\
\hline 6 & 45 & 70 & 80 & 79 \\
\hline 6.5 & 69 & 100 & 100 & 100 \\
\hline 7 & 90 & 80 & 76 & 90 \\
\hline 7.5 & 100 & 50 & 43 & 60 \\
\hline 8 & 78 & 30 & 32 & 43 \\
\hline 8.5 & 56 & 19 & 12 & 34 \\
\hline 9 & 43 & 10 & 8 & 16 \\
\hline 9.5 & 23 & 4 & 4 & 0 \\
\hline 10 & 18 & 0 & 0 & 0 \\
\hline
\end{tabular}


Streptomyces sp., T. thermophilus ve Clostridium thermosulfurogenes'ten elde edilen glikoz izomerazların optimum pH'ları 7.0'dir (Karaoğlu vd., 2013). Tablo 2, dört termofilik izolatın 85 ${ }^{\circ} \mathrm{C}$ 'de 30 dakika sonra ölçülen enzim aktivitesinin pH bağımlılığını gösterir. BT5, CT6SARI ve CT1.2 glikoz izomerazlar1 pH6.5' da en yüksek aktivite göstermektedir. Bu özelliği ile enzimler, özellikle endüstriyel olarak arzu edilen asidik $\mathrm{pH}$ değerlerine, birçok mikroorganizmanın glikoz izomerazına göre, daha yakındır. Bu enzimler, 6.0 ile 7.0 arasında daha düşük bir pH'ye sahip Lactobacillus brevis gibi endüstriyel uygulamalar için uygun oldukları ve yüksek kullanım potansiyeline sahip oldukları düşünülmektedir.

\subsection{Glikoz İzomeraz Üreten İzolatların Morfolojik Karakterizasyonu}

Yapılan boyamalar ve mikroskop incelemeler sonucunda, dört izolat hücresinin çubuk şeklinde, Gram pozitif ve endospor olușturan bakteriler oldukları belirlendi. Olgun sporlar, aerobik olarak yetiştirilen kültürlerde bol miktarda gözlemlendi.
Tüm izolatlarda sub-terminal sporlar gözlemlendi, ancak CT6SARI ve BT1 izolatlarının ayrica merkezi sporlara da sahip oldukları belirlendi. Sporulasyon, tüm izolatlarda $60{ }^{\circ} \mathrm{C}^{\prime} \mathrm{de} 18$ saat inkübasyon sonrası gözlendi.

\subsection{S rRNA Gen Dizisi Analizi}

Dört izolatın 16S rRNA gen dizileri hizalandı ve ilgili bakterilerin dizileri ile karşılaştırıldı. Filogenetik ağaç, neighbour-joining yöntemi ile MEGA4 paket programı kullanılarak oluşturuldu (Şekil 1). 16S rRNA gen dizisi analizine dayanarak, dört izolatın Geobacillus cinsine ait türlere $\geq \% 97$ benzerlik gösterdiği ve Geobacillus cinsinin üyeleri oldukları belirlendi.

Stackebrandt ve Goebel (1994), \% 97'den daha az 16S rRNA gen dizilimi benzerliği gösteren aynı cins ait suşların, farklı bir türün üyeleri olarak değerlendirilmesi gerektiğini belirledi. Bununla birlikte literatürde, $16 \mathrm{~S}$ rRNA dizilerinin analizinin yakından ilişkili bazı türleri ayırt etmek için yetersiz olduğu da belirtilmektedir.

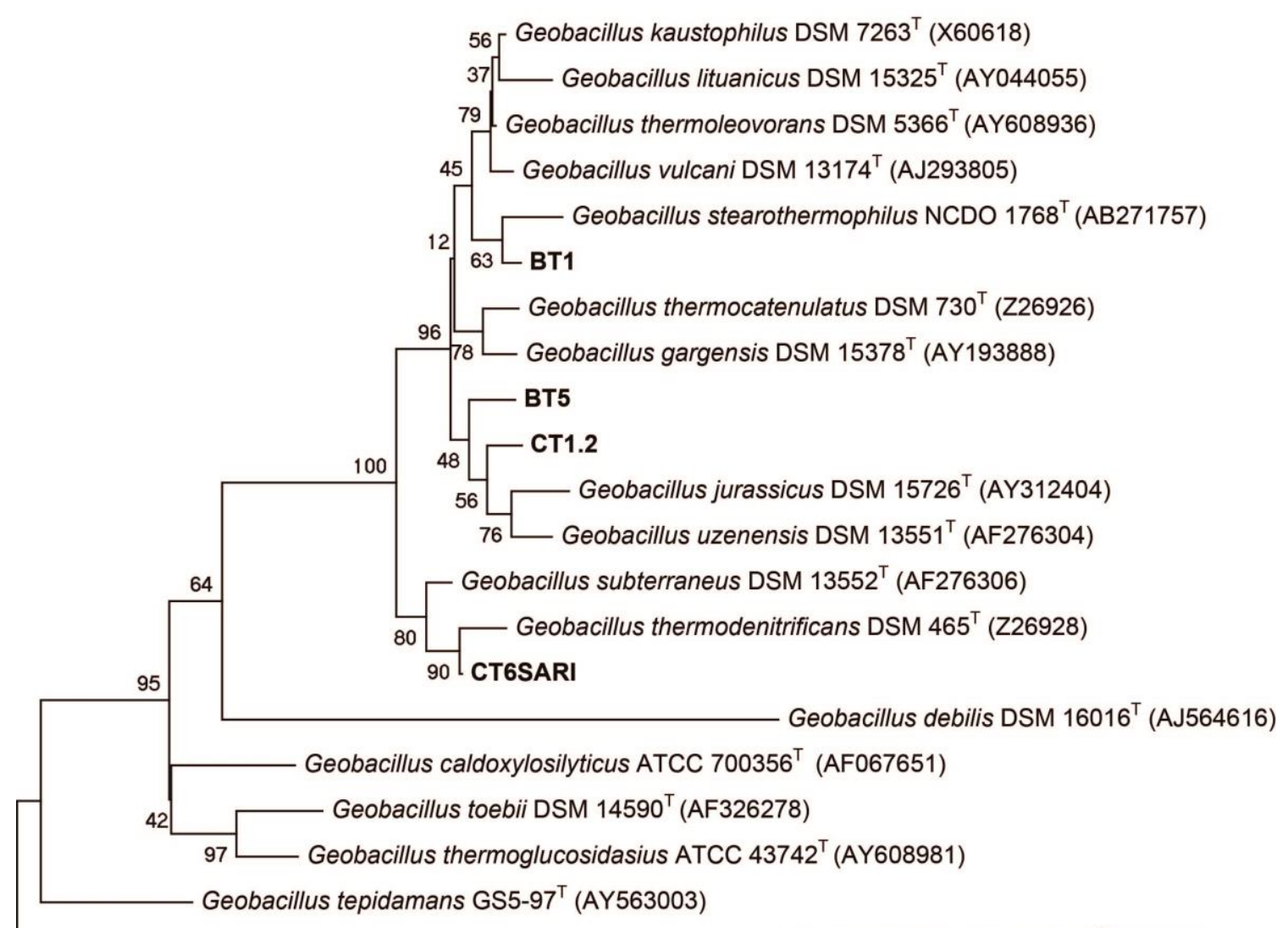

Bacillus subtilis NCDO $1769^{\top}$ (X60646)

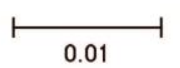

Şekil 1. Filogenetik ağaç, dört termofilik izolat ve diğer ilgili organizmaların 16S rRNA gen sekans1 verilerine dayanarak neigbour-joining yöntemi ile oluşturuldu. 
16S rRNA gen dizisi verileri cins seviyesinde bakterilerin tanımlanması için oldukça faydalı olmasına rağmen, tür seviyesinde genellikle yeterli olmadığ verileri, tür seviyesinde bakterileri ayırt etmek için daha güçlü ve güvenilir yaklaşım olduğu düşünülen diğer genomik yöntemlerle desteklenmelidir.

\section{4. $\operatorname{recN}$ Gen Dizisi Analizi}

16S rRNA dizilerinin sonuçlarına dayanarak, dört izolatın, Geobacillus cinsinin üyeleri olduğu tespit edildi. Dört izolatın recN gen dizileri belirlendi, hizaland 1 ve ilgili bakterilerin dizileri ile karşılaştırıldı. Filogenetik ağaç, neighbour-joining yöntemi kullanılarak oluşturulmuştur (Şekil 2). $r e c N$ gen dizilerinin benzerlikleri incelendiğinde, CT6SARI izolatının $r e c N$ dizisinin, $G$. thermodenitficans recN dizisine \% 99; BT1 recN dizisinin, G. stearothermophilus recN dizisine \% 99; BT5 ve CT1.2 recN dizilerinin, Grup 3 recN dizilerine (G. termoleoverans, G. kaustophilus, G. vulcani, G. lituanicus, G. stearothermophilus ve G. thermocatenulotis) \% 91oranında benzerlik gösterdikleri ortaya çıkarıldı.

Zeigler (2003), recN dizi karşılaştırmalarının, Geobacillus cinsi için genom benzerliklerini doğru bir şekilde ölçebileceğini ve eğer iki bakteri izolatı için recN DNA dizileri \% 84'ten daha az benzer ise, genom dizilerinin \% 70 aynı olduğunu ve bakterilerin farklı türlere ait olduğunu ortaya koydu. recN DNA sekansları \% 96'dan fazla benzer ise, \% 95 eminlikle bakterilerin aynı türe ait oldukları belirlenebilir. Eğer recN dizileri \% 84 ile \% 96 arasında benzerlik gösteriyor ise, genom dizilimi özdeşliğinin \% 70'den büyük ya da daha düşük olup olmadığı sorgulanabilir, bu da bu bakterilerin tür kimliklerini belirsiz hale getirir. Zeigler (2005), Geobacillus türlerini, dokuz homoloji grubu (Grup 1A, 1B, 2, 3, 4A, 4B, 5, $6 \mathrm{~A}, 6 \mathrm{~B})$ içerisine yerleştirdi. Gruplar 1A, 2, 4A, 5 ve 6 A sirasiyla, $G$. termodenitrificans, $G$. stearothermophilus, G. thermoglucosidasius, G. toebii ve G. caldoxylosilyticus türlerini içermektedir. Hâlihazırda tanınan türler ile diğer dört homoloji grubunun (1B, 3, 4B ve 6B) tanımlanması biraz daha zordur.

recN dizisi benzerlik analizi sonuçlarına dayanarak, izolat CT6SARI izolatının, $G$. termodenitficans'a; izolat BT5'in de, $G$. stearothermophilus'a ait yeni birer suş oldukları belirlendi. BT5 ve CT1.2 izolatlarının kesin tür tayinleri ise mevcut analizler sonucunda belirlenemedi. BT5 ve CT1.2 izolatlarının recN dizileri yukarıda tartış1lan Geobacillus türlerine \% 91 oranında benzerlik gösterdiği için, $r e c N$ dizi analizi tür analizi için kesin sonuç verememektedir ve daha fazla analize ihtiyaç duyulmaktadır. $\mathrm{Bu}$ çalışma kapsamında, Geobacillus cinsine ait glikoz izomeraz üreten dört yeni termofilik bakteri izole edildi, sistematik çalışmaları yapıldı ve dört izolatın glikoz izomeraz aktiviteleri incelendi.

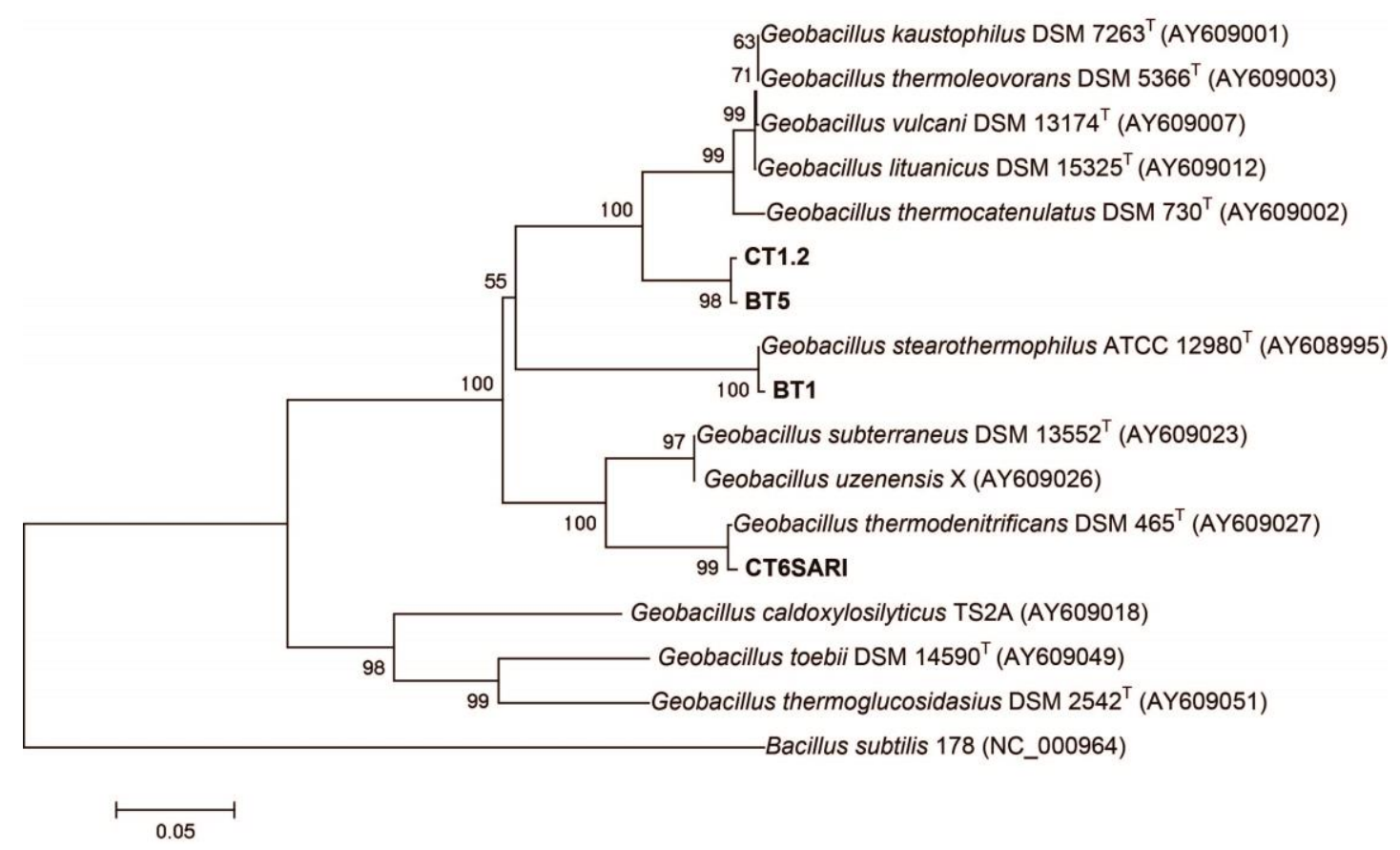

Şekil 2. Filogenetik ağaç, neigbour-joining yöntemi kullanarak dört Geobacillus izolatının ve diğer ilgili organizmaların $r e c N$ gen dizi verilerine dayanılarak oluşturulmuştur. 
Sonuç olarak izole edilen bakterilerin, literatürde mevcut glikoz izomerazlara kıyasla daha iyi özelliklere sahip glikoz izomerazlara sahip olduklar1 ve bu enzimlerin endüstrinin ihtiyaçlarını karşılayabilecek potansiyele sahip oldukları düşüncesindeyiz.

\section{Sonuç}

Asidik pH ve yüksek sicaklıkta optimum aktiviteye sahip olan bir glikoz izomeraz, renkli karbonil bileşiklerinin oluşumunu azaltır ve daha düşük iyon değişimi ve karbon temizleme maliyetine yol açar. $\mathrm{Bu}$ nedenle, daha yüksek sicaklıklarda ve asidik ortamda faal olarak aktif olan glikoz izomerazlar, endüstriyel uygulamalar için arzu edilen enzimlerdir.

$\mathrm{Bu}$ nedenle bu çalışmanın amacı, farklı iki kaplicadan termofilik bakterilerin izole edilip, glikoz izomeraz aktivitelerinin araştırılması, enzimlerin optimum sıcaklık ve $\mathrm{pH}$ değerlerinin belirlenip yüksek sıcaklık ve düşük pH'larda aktif olan ve endüstriyel kullanım potansiyeline sahip enzimlerin bulunması, enzim üretici bakterilerin 16S rRNA ve recN analizlerinin yaplarak tanımlanmaları ve sinıflandırılmalıdır. Bu sebeple izole dilen 23 termofilikizolatın glikoz izomeraz aktiviteleri tarand 1 ve glikoz izomeraz aktivisine sahip dört izolat (BT1, BT5, CT6SARI ve CT1.2) bulundu. $\mathrm{Bu}$ dört izolatın ürettikleri glikoz izomerazlarının optimum sicaklık ve $\mathrm{pH}$ aralıkları belirlendi. BT5, CT6SARI ve CT1.2 glikoz izomerazlarıpH $6.5^{\prime}$ da ve $80{ }^{\circ} \mathrm{C}$ 'de en yüksek aktivite gösterdikleri, BT1'in isepH 7.5'da ve 75 ${ }^{\circ} \mathrm{C}$ 'de optimum aktivite gösterdiği belirlendi.

Sonuç olarak bu bağlamda, özellikle BT5, CT6SARI ve CT1.2 izolatlarının ürettikleri glikoz izomerazlarının, biyoteknolojik uygulamalar için iyi birer aday olabilecekleri düşünülmektedir ancak bunun için daha ileri araştırmalarla desteklenmesi gerekmektedir.

\section{Kaynaklar}

Abdel-rassol, T.M.A., Badr, S.A. ve Omran, H.T., 2012. Glucose (xylose) isomerase production from thermotolerant and thermophilic bacteria, African Journal of Biotechnology, 11, 15798-15801.

Altschul, S.F., Gish, W. ve Miller, W., 1990. Basic local aligment search tool, Journal Molecular Biology, 215, 403-410.
Bandlish, R.K., Michael, H.J., Epting, K.L., Vieille, C. ve Kelly, R.M., 2002. Glucoseto-fructose conversion at high temperatures with xylose (glucose) isomerases from Streptomyces murinus and two hyperthermophilic Thermotoga species. Biotechnology Bioenergy, 80, 185-194.

Beffa, T., Blanc, M., Lyon, P.F., Vogt, G., Marchiani, M., Fischer, J.L. ve Aragno, M., 1996. Isolation of Thermus strains from hot compost (60 to $\left.80{ }^{\circ} \mathrm{C}\right)$. Applied and Environmental Microbiology, 62, 17231727.

Beg, O.K., Bhushan, B., Kapoor, M. ve Hoondal, G.S., 2000. Production and characterization of thermostable xylanase and pectinase from Streptomyces sp. QG-11-3, Journal of Industrial Microbiology and Biotechnology, 24, 396-402.

Benson, D.A., Boguski, M.S., Lipman, D.J., Oulette, B.F.F., Rapp, B.A. ve Wheelet, D.L., 1999. GenBank, Nucleic Acids Research, 27, 12-17.

Bhosale, S.H., Rao, M.B. ve Deshpande, V.V., 1996. Molecular and industrial aspects of glucose isomerase, Microbiological Reviews, 60, 280-300.

Brosius, J., Palmer, M.L., Kennedy, P.J. ve Noller, H.F., 1978. Complete nucleotide sequence of a $16 \mathrm{~S}$ ribosomal RNA gene from Escherichia coli, Proceedings of the National Academy of Sciences of the United States, 75, 4801-4805.

Calik, P., Angardi, V. ve Isik, N., 2009. Glucose isomerase production on a xylan-based medium by Bacillus thermoantarcticus, Biochemical Engineering Journal, 43, 8-15.

Canakci, S., Inan, K., Kacagan, M. ve Belduz, A.O., 2007. Evaluation of Arabinofuranosidase and Xylanase Activities of Geobacillus spp. Isolated from Some Hot Springs in Turkey, Journal of Microbiology and Biotechnology, 17, 1262-1270.

Chauthaiwale, J.V. ve Rao, M.B., 1994. Production and purification of extracellular xylose 1somerase from an alkaliphilic, thermophilic Bacillus sp, Applied Environmental Microbiology, 60, 44954499. 
Dische, Z. ve Borenfreund, E., 1951. A new spectrophotometric method for the detection and determination of ketosugars and trioses, The Journal of Biological Chemistry, 192, 583-587.

Dussault, HP., 1955. An improved technique for staining red halophilic bacteria. Journal Bacteriology, 70, 484-485.

Felsenstein, J., 1985. Confidence limits on phylogenies: an approach using the bootstrap, Evolution, 39, 783-791.

Hartley, B.S., Hanlon, N., Jackson, R.J., Rangarajan, M., 2000. Glucose isomerase: insights into protein engineering for increased thermostability. Biochimica et Biophysica Acta, 1543, 294-335.

Hess, J.M., Tchernajenko, V., Vieille, C., Zeikus, J.G. ve Kelly, R.M., 1998. Thermotoga neapolitana Homotetrameric Xylose Isomerase is Expressed as a Catalytically Active and Thermostable Dimer in Escherichia coli, Applied Environmental Microbiology, 64, 2357-2360.

Inan, K., Canakci, S., Belduz, A.O. ve Sahin, F., 2011. Brevibacillus aydinogluensis sp. nov., a moderately thermophilic bacterium isolated from Karakoc hot spring in Turkey. International Journal of Systematic and Evolutionary Microbiology, 62, 849-855.

Inyang, C.U., Gebhart, U., Obi, S.K.C. ve Bisswanger, H., 1995. Isolation and characterization of a d-glucose/xylose 1somerase from a new thermophilic strain Streptomyces sp. (Plc), Applied Microbiology Biotechnology, 43, 632-638.

Karaoğlu, H., Yanmis, D., Sal, F.A., Celik, A., Canakci, S. ve Belduz, A.O., 2013. Biochemical characterization of a novel glucose isomerase from Anoxybacillus gonensis $\mathrm{G} 2^{\mathrm{T}}$ that displays a high level of activity and thermal stability. Journal of Molecular Catalysis B: Enzymatic, 97, 215224.

Kimura, M., 1980. A simple method for estimating evolutionary rates of base substitutions through comparative studies of nucleotide sequences, Journal of Molecular Evolution 16, 111-120.
La Duc, M.T., Satomi, M. ve Agata, N., 2004. gyrB as a phylogenetic discriminator for members of the Bacillus anthracis-cereusthuringiensis group, Journal of Microbiological Methods, 56, 383-394.

Lehmbacher, A. ve Bisswanger, H., 1990, Isolation and characterization of extremely thermostable D-xylose 1somerase from Thermus Aquaticus Hb8, Journal Genom Microbiolology, 136, 679-686.

Liu, S.Y., Wiegel, J. ve Gherardine, F.C., 1996. Purification and cloning of a thermostable xylose (glucose) 1somerase with an acidic ph optimum from Thermoanaerobacterium strain Jw/Sl-Ys 489, Journal Bacteriology, 178, 5938-5945.

Meintanis, C., Chalkou, K.I. ve Kormas, K.A., 2008. Application of $r p o B$ sequence similarity analysis, REP-PCR and BOXPCR for the differentiation of species within the genus Geobacillus, Letters in Applied Microbiology, 46, 395-401.

Mu, W., Wang, X., Xue, Q., Jiang, B., Zhang, T. Ve Miao, M., 2012. Characterization of a thermostable glucose isomerase with an acidic $\mathrm{pH}$ optimum from Acidothermus cellulolyticus. Food Research International, 47, 364-367.

Nazina, T.N., Tourova, T.P., Poltaraus, A.B., Novikova, E.V., Grigoryan, A.A., Ivanova, A.E., Lysenko, A.M., Petrunyaka, V.V., Osipov, G.A., Belyaev, S.S. ve Ivanov, M.V., 2001. Taxonomic study of aerobic thermophilic bacilli: descriptions of Geobacillus subterraneus gen. nov., sp. nov. and Geobacillus uzenensis sp. nov. from petroleum reservoirs and transfer of Bacillus stearothermophilus, Bacillus thermocatenulatus, Bacillus thermoleovorans, Bacillus kaustophilus, Bacillus thermoglucosidasius and Bacillus thermodenitrificans to Geobacillus as the new combinations $G$. stearothermophilus, $G$. thermocatenulatus, $G$. thermoleovorans, $G$. kaustophilus, G. thermoglucosidasius and G. thermodenitrificans, International Journal of Systematic and Evolutionary Microbiology, 51, 433-446.

Powers, E.M., 1995. Efficacy of the Ryu nonstaining $\mathrm{KOH}$ technique for rapidly determining Gram reactions of food-borne 
and waterborne bacteria and yeasts, Applied and Environmental Microbiology, 61, 3756-3758.

Schenck, F., 2000. High fructose syrups - a review, Indian Sugar, 50, 281-287.

Sharma, A., Pandey, A, ve Shouche, Y.S., 2008. Characterization and identification of Geobacillus spp. isolated from Soldhar hot spring site of Garhwal Himalaya, India, Journal Basic Microbiolgy, 48, 1-8.

Smibert, R.M. ve Krieg, N.R. 1994, Phenotypic characterization. In Methods for General and Molecular Bacteriology. Gerhardt, P., Murray, R.G.E., Wood, W.A. and Krieg N.R. (eds.), Washington, DC: American Society for Microbiology. pp. 607-654.

Stackebrandt, E. ve Goebel, B.M., 1994. Taxonomic note: a place for DNA-DNA reassociation and $16 \mathrm{~S}$ rRNA sequence analysis in the present species definition in bacteriology, International Journal of Systematic and Evolutionary Microbiology, 44, 846-849.

Stackebrandt, E., Frederiksen, W. ve Garrity, G.M., 2002. Report of the ad hoc committee for the re-evaluation of the species definition in bacteriology, International Journal of Systematic and Evolutionary Microbiology, 52, 1043-1047.

Tamura, K., Dudley, J. ve Nei, M., 2007. MEGA4: Molecular evolutionary genetics analysis (MEGA) software version 4.0, Molecular Biology and Evolution, 24, 1596-1599.

Thompson, J.D., Higgins, D.G. ve Gibson, T.J., 1994. CLUSTAL W: improving the sensitivity of progressive multiple sequence alignment through sequence weighting, position-specific gap penalties and weight matrix choice, Nucleic Acids Research, 22, 4673-4680.

Touzel, J.P., O’donohue, M. ve Debeire, P., 2000. Thermobacillus xylanilyticus gen. nov., sp. nov., a new aerobic thermophilic xylandegrading bacterium isolated from farm soil. International Journal of Systematic and Evolutionary Microbiology, 50, 315-320.

Yamanaka, K., 1975. D-Xylose isomerase from Lactobacillus brevis, Methods Enzymology, 41, 466-471.

Yanmış, D., Karaoğlu, H., Çolak, D.N., Sal, F.A., Çanakc1, S. ve Belduz A.O., 2014. Characterization of a novel xylose isomerase from Anoxybacillus gonensis $\mathrm{G} 2^{\mathrm{T}}$. Turkish Journal of Biology, 38, 586592.

Xu, H., Shen, D., Wu, X.Q., Liu, Z.W. ve Yang, Q.H., 2014. Characterization of a mutant glucose isomerase from Thermoanaerobacterium saccharolyticum, Journal Indian Microbiology Biotechnology, 41, 15811589.

Zeigler, D.R., 2003. Gene sequences useful for predicting relatedness of whole genomes in bacteria, International Journal of Systematic and Evolutionary Microbiology, 53, 18931900 .

Zeigler, D.R., 2005. Application of a recN sequence similarity analysis to the identification of species within the bacterial genus Geobacillus, International Journal of Systematic and Evolutionary Microbiology, 55, 1171-1179. 